\title{
Fungal Diseases in Some Leafy Vegetables Growing Areas in Turkish Republic of Northern Cyprus
}

\author{
Aysegul Colak Ates \\ Biological Control Research Institute, Department of Phytopathology, \\ Kisla St. 01321 Yuregir, Adana, Turkey \\ E-mail: aysegulcolak@hotmail.com
}

\begin{abstract}
Fungi are one of the plant disease pathogen groups that restrict economic production in leafy vegetable growing. In this study, one of the leafy vegetables that eat an important place in our food is; It is aimed to determine the pathogens of fungal disease, which are the leading factors that limit the production of parsley, arugula, mint, spinach and lettuce. For this purpose, the study was carried out in the production areas of Guzelyurt, Gazimagusa, Girne, Iskele and Lefkoşa provinces in Turkish Republic of Northern Cyprus (TRNC) between 2014-2016, and fungal disease pathogens and prevalence rates were determined. At the end of the studies; Septoria petroselini, Alternaria petroselini, Fusarium oxysporum, Rhizoctonia solani in parsley; Albugo candida, Alternaria japonica, Rhizoctonia solani, Fusarium oxysporum in arugula; Rhizoctonia solani, Fusarium oxysporum, Verticillium dahliae in mint; Albugo occidentalis, Colletotrichum dematium, Cercospora beticola, Peronospora farinosa f.sp. spinaciae, Fusarium oxysporum in spinach; Sclerotinia sclerotiorum, Bremia lactucae, Fusarium oxysporum in lettuce, fungal diseases were detected.
\end{abstract}

Keywords: Leafy vegetables, lettuce, spinach, parsley, arugula, mint, fungal disease

DOI: $10.7176 / \mathrm{JSTR} / 6-09-08$

\section{Introduction}

Vegetables are important for human nutrition in terms of macro and micro nutrients such as carbohydrates, fats, proteins, vitamins and minerals they contain. Vegetables that eat leaf, which is a rich source of minerals and vitamins, are important dietary products with low calories as well as containing important antioxidant compounds. In addition, the extracts of these plants are used in the food industry, cosmetics and medicine (Gupta and Prakash, 2009). Plant fungal diseases can lead to great economic losses in the production of leafy vegetables and decrease the market value of the product. According to the data of the Turkish Republic of Northern Cyprus (TRNC) 2016, the vegetables that are eaten in leaf form $5.559 \mathrm{da}$, which is $0.4 \%$ of the agricultural land part in which crops are planted in 992.264 da. In this context, among the products eaten with leaves in the country, the most production area is lettuce with 590 da, spinach with 204 da, parsley with 77 da and others (Anonymous, 2017).

Lettuce (Lactuca sativa), which is the delicious and nutritious element of our salads in every season of the year, is a vegetable in the Asteraceae family, whose leaf is eaten, consumed with plenty of vitamins and minerals and appetizing vegetables. The most common diseases in lettuce are lettuce mildew (Bremia lactucae), white rot (Sclerotinia sclerotiorum), gray mold (Botrytis cinerea), root rot (Rhizoctonia solani) and anthracnose (Microdochium panattonianum) (Çolak, 2019; Onar and Yanar, 2009; Budge and Whipps, 2001; Fiume and Fiume, 2005; Fiddaman et al., 2000). When studies conducted in many countries around the world are examined, the most damaging fungal diseases in spinach, which have an important place among the leafy, are mildew (Peronospora farinosa f.sp. spinaciae), white rust (Albugo occidentalis), leaf spot diseases (Cladosporium variabile, Stemphylium botryosum), there are various diseases caused by soil-borne fungal diseases (Fusarium oxsyporum f.sp. spinaciae, Pythium aphanidermatum, Pythium irregulare, Rhizoctonia solani and Aphanomyces cochlioides) (Feng et al., 2014; Correll et al., 1994; Raid and Roberts, 2009; Dainello et al., 1990; Koike et al., 2007; Irish et al., 2007). The leaves and roots of parsley (Petroselinum crispum), which is

$80 \mid P$ a g e

www.iiste.org 
one of the vegetables eaten with leaves, are used as food and its oil is used for plant protection. In many countries, parsley is a fragrant vegetable rich in vitamin E, which is not missing from the market for 12 months. It is an indispensable vegetable of food and salads. Parsley has an important place in economic income by providing producers with constant income throughout the year. Important fungal diseases detected in parsley are powdery mildew (Erysiphe heraclei), leaf spot (Alternaria dauci, Septoria petroselini), root rot caused by soil-borne fungal diseases (Fusarium oxysporum, Fusarium solani, Pythium ultimum, Pythium irregulare, Rhizoctonia solani ande white rots (Sclerotinia sclerotiorum) (Tok and Kurt, 2019; Glawe et al., 2005; Tok, 2008; Kurt, 2003; Soylu et al., 2010).

Mint, which is one of the Labiatae family vegetables (Mentha x piperita: peppermint; Mentha spicata: spearmint), is a multi-year aromatic vegetable (Alonso et al., 1992). Mint contains essential oils, especially menthol and tannins, and they are of great importance in the medical plants class. Mint is used as a tea in addition to being used in meals, salads, pickles as well as fresh and dry. Mint, a plant that is also sought in perfume, peppermint oil, spirits, chewing and pharmaceutical industry, is also widely used in the treatment of various diseases in the human body (Kalra et al., 2005; Özgüven and Kırıc1, 1999; Demir, 2007). The most common diseases in mint are Fusarium and Verticillium wilt (Fusarium oxysporum, Verticillium dahliae), root rot and rust (Puccinia menthae). Apart from these main factors, it is possible to encounter other diseases such as fungal disease factors, anthracnose, septoria leaf spot, which are seen in mint over the years due to climate factors (Ellialtığlu et al., 2002; Özgüven and Kırıc1, 1999). Arugula, which has been considered as a vegetable since the Roman period, is produced as an oil plant in far eastern countries such as India and China (Demir 2007). The important fungal diseases of the arugula are white rust (Albugo candida), leaf spot (Alternaria japonica) and Fusarium wilt (Scheck and Koike, 1999; Srinivasan et al., 2009; Garibaldi et al., 2011). The study was carried out on the fact that some leafy vegetables, which are indispensable for the foods and salads in TRNC, have economically restricted diseases and the market value of the product and the complaints of farmers have increased. The purpose of our study is to identify fungal diseases in the some leafy vegetable production areas in the region.

\section{Materials and Methods}

The main material of the study consisted of samples from plants showing fungal disease in the fields where parsley, arugula, mint, spinach and lettuce were grown in Gazimağusa, Güzelyurt, İskele, Lefkoşa ve Girne county between 2014-2016 in TRNC. In the study, diseased plant sampling was carried out in 74 fields covering 354.7 of 5 county (Table 1). In the study, disease determinations were made according to random sampling method and at least $1 \%$ of the cultivation areas. The studies were carried out in fields that were chosen by chance and whose size was over 0.5 decare. During sampling in the field; according to the records kept as disease, no disease, the percentage (\%) contamination rates of the disease pathogens were calculated with the simple average method (Bora and Karaca, 1970). For this purpose, counts were made for each disease in plants entering into it by laying a $1 \mathrm{~m}^{2}$ wire frame in the direction of the diagonals by leaving a margin share from a production area. Counting results of plants hitting the wire in 3 points if the field size is 0-0.5 da, 5 points if $1-5 \mathrm{da}, 10$ points if 6-10 da, 15 points in fields over $10 \mathrm{da}$, and at least 10 plants in lettuce It is stated as a percentage $(\%)$. Disease rate in the production area was calculated on the percent $(\%)$ infected plant. After determining the capture rates on the basis of the field, the prevalence rate at the regional level; the prevalence rate of the region (\%): (disease rate in the field (\%) x area of the field (da) / Maximum disease probability) X100 was found according to the formula (Bora and Karaca, 1970). During field controls; For each type of symptom observed, samples were taken and brought to the laboratory in an ice box after being placed in a paper bag. Diseased plant samples collected were labeled and kept at $+4^{0} \mathrm{C}$ for diagnostic studies of fungal disease. As a result of the diagnostic work; the field in which disease diagnoses were made was accepted as a dishwashing with that disease and \% prevalence rates of the disease were calculated (Bora and Karaca, 1970; Karman, 1971).

For this purpose, fungus isolations; roots, stems and leaves taken from plants with symptoms of disease were collected on paper bags. 2-3 mm sized plant pieces were cut with a clean scalpel with plant parts, patient and healty tissues. Afterwards, these parts were kept in a sterile cabinet in a $1 \%$ sodium hypochlorite (NaOCI) solution for 2-3 minutes and surface sterilization was performed. The plant tissue pieces that were surface sterilized were passed through sterile distilled water twice and the $\mathrm{NaOCI}$ residue was removed and transferred to sterile blotting paper in order to remove excess water in the tissue. Potato Dextrose Agar (PDA) and selective feeding media Synthetic Nutrient Agar (SNA) were planted in $9.0 \mathrm{~cm}$ Petri dishes containing Water agar for species diagnosis of disease factors. For Petri dishes were incubated at $24 \pm 1{ }^{\circ} \mathrm{C}$ for 7-10 days (Çolak and Biçici, 2013; Çolak et al., 2018). Following the incubation, isolates were tested for pathogenicity test and re-isolated, and the two

81 | P a g e 
isolates belonging to each county were identified using the diagnostic keys given in the literature. For Biotroph fungi, the typical and scraping preparations they create in the plant were examined under a microscope and made use of diagnostic keys (Agrios, 2005; Sherf and Alan, 1986; Sneh et al., 1991; Correll et al., 1994; Garibaldi et al., 2011; Sherf and MacNab, 1986; Washington et al., 2006; Smolinska and Kowalska, 2018; Booth 1971; Mullen, 2001; Mordue 1974; Singleton et al., 1992; Koike et al.,. 2007).

\section{Results and Discussion}

In the study, fungal diseases isolated from sickly plant samples from leafy vegetables, parsley, arugula, mint, spinach and lettuce were obtained from Güzelyurt, Gazimağusa county, followed by Girne, İskele and Lefkoşa. The prevalence rate of diseases in the production fields of Güzelyurt region is $29.26 \%$ of Septoria petroselini, $2.23 \%$ of Alternaria petroselini, $12.35 \%$ of Fusarium oxysporum, Rhizoctonia solani $1.12 \%$ in parsley; Albugo candida $20.41 \%$, Alternaria japonica $2.65 \%$, Rhizoctonia solani $1.09 \%$ in arugula; Rhizoctonia solani $8.20 \%$, Fusarium oxysporum $6.53 \%$, Verticillium dahliae $1.89 \%$ in mint; Albugo occidentalis 18.16\%, Colletotrichum dematium 7.64\%, Cercospora beticola $3.84 \%$, Peronospora farinosa f.sp. spinaciae $1.16 \%$ in spinach, Sclerotinia sclerotiorum $36.28 \%$, Bremia lactucae $18.72 \%, 1.67 \%$ Fusarium oxysporum in lettuce are identified as fungal pathogens (Table 2). In the studies carried out in the Gazimağusa region, Septoria petroselini with $22.45 \%$ prevalence rate, Fusarium oxysporum with $14.64 \%$ prevalence rate, Rhizoctonia solani with $0.50 \%$ prevalence rate and Alternaria petroselini with $6.91 \%$ prevalence were found in parsley. Albugo candida with $16.72 \%$ prevalence rate, Alternaria japonica with $1.44 \%$ prevalence rate and $1.16 \%$ Fusarium oxysporum were found in arugula areas. In mint fields; Rhizoctonia solani with a prevalence rate of $12.14 \%$ and Fusarium oxysporum with a prevalence rate of $8.83 \%$ were found. In the areas where spinach is grown; Albugo occidentalis with $26.65 \%$ prevalence rate, Colletotrichum dematium with $2.24 \%$ prevalence rate, Cercospora beticola with $1.83 \%$ prevalence rate, $1.22 \%$ Peronospora farinosa f.sp. spinaciae fungal disease pathogens have been identified. In lettuce fields, Sclerotinia sclerotiorum with $28.50 \%$ prevalence rate and Bremia lactucae fungal disease pathogens with $13.67 \%$ prevalence rate were detected (Table 2).

In the fields in which parsley is grown from vegetables that eat leaves in the Girne region, Alternaria petroselini with $3.52 \%$ prevalence rate, Septoria petroselini with $2.83 \%$ prevalence rate and Rhizoctonia solani with $2.15 \%$ prevalence rate in parsley; Albugo candida with $8.82 \%$ prevalence rate and Alternaria japonica with $1.36 \%$ prevalence rate in arugula; Fusarium oxysporum with a prevalence rate of $3.27 \%$ in mint; Albugo occidentalis with $15.98 \%$ prevalence rate, Cercospora beticola with $1.91 \%$ prevalence rate, Colletotrichum dematium with $1.54 \%$ prevalence rate and Fusarium oxysporum with $2.62 \%$ prevalence in spinach; In lettuce, Sclerotinia sclerotiorum with $18.32 \%$ prevalence rate, Bremia lactucae with $8.74 \%$ prevalence rate and Fusarium oxysporum with $1.23 \%$ prevalence rate, fungal disease pathogens have been identified (Table 2).

In the fields where parsley is grown in the İskele region; Alternaria petroselini with a prevalence rate of $1.62 \%$, Septoria petroselini with a prevalence rate of $1.23 \%$; Albugo occidentalis with $2.14 \%$ prevalence rate, Fusarium oxysporum with $8.41 \%$ prevalence rate, Cercospora beticola with $1.12 \%$ prevalence rate in spinach; Sclerotinia sclerotiorum with a prevalence rate of $8.18 \%$ and Bremia lactucae with a prevalence rate of $2.37 \%$ in lettuce area, fungal disease pathogens were found. Lettuce from leafy vegetables in the Lefkoşa region were fungal pathogens identified with Sclerotinia sclerotiorum with a prevalence rate of $15.42 \%$, Bremia lactucae with a prevalence of $8.22 \%$ and Fusarium oxysporum with $1.48 \%$ prevalence rate (Table 2).

In the study, the most common fungal disease factor in the areas where parsley was grown from vegetables eaten with leaf is Septoria leaf spot disease caused by Septoria petroselini, and Fusarium oxysporum, Rhizoctonia solani, Alternaria petroselini were found at lower rates (Tok and Kurt, 2019; Nawrock, 2004; Soylu et al., 2010; Tok, 2008; Glawe et al., 2005; Hershman, 1986). Septoria petroselini forms pycnidia in small black-brown spots on the leaves and stems of the disease plant (Figure 1) The spread of the disease occurs with rain, wind and insects on another plant of these spores, which are formed on diseased plant residues. The disease has a fairly large host. The disease can be seen in lettuce, parsley, onion, celery, zucchini, and tomato. In the control against the disease, it is necessary to use clean (disease-free) seeds, crop rotation, the diseased plants and harvest residues to be collected and destroyed. Chemical control against the disease should be started as soon as the first symptoms of the disease are seen in the environment (Tok and Kurt, 2019; Anonymous, 2020). Turkey in intensive parsley is grown in the Mediterranean region of Hatay province fungal disaese pathogen Septoria petroselini, it was first identified by Kurt (2003). The incidence of the disease in the region was determined to be $42-80 \%$.

82 | P a g e

www.iiste.org 
The effects of different fungicides on germination, mycelial development, seed transport and infection of the spores of Septoria petroselini in parsley were investigated. Azoxystrobin, benomyl, cresoximmethyl, trifloxystrobin and tebuconazole have been found to be effective on this disease in pot experiments. Mancozeb and maneb were effective only when applied before inoculation, copper oxychloride was unsuccessful in all trials (Tok, 2008).In order to reduce the use of pesticides due to the fact that parsley is a leaf-eaten vegetable and the use of excess pesticides, both environmental and health problems and economic problems, some alternative methods for controlling the disease have come to the agenda. In the study, it was determined that the rate of infected seedlings fell to $20 \%$ in seeds kept at $55^{\circ} \mathrm{C}$ for 30 minutes, therefore, the transportation of $S$. petroselini was blocked by $80 \%$ at this temperature. With this study, it was determined that the application of hot water significantly reduced the transport of $S$. petroselini with seeds. Therefore, with the use of this method, it is thought that the prevalence of the disease and loss of yield will decrease significantly (Tok and Kurt, 2019). Sudden wilt disease, effective in parsley seedlings, caused great losses in the 1981-1982 production season in South New Jersey. Fusarium oxysporum, Fusarium solani, Pythium ultimum, Pythium irregulare and Rhizoctonia solani were isolated from the seedlings with symptoms (Hershman,1986). In a study conducted on parsley seedlings, the greenhouse and field conditions, Seedlings were found to be the most Alternaria radicina and Fusarium spp. In the study, Cylindrocarpon destructans, Rhizoctonia solani and Stemphylium botryosum were detected in some parsley seedlings under field conditions (Nawrocki, 2004).

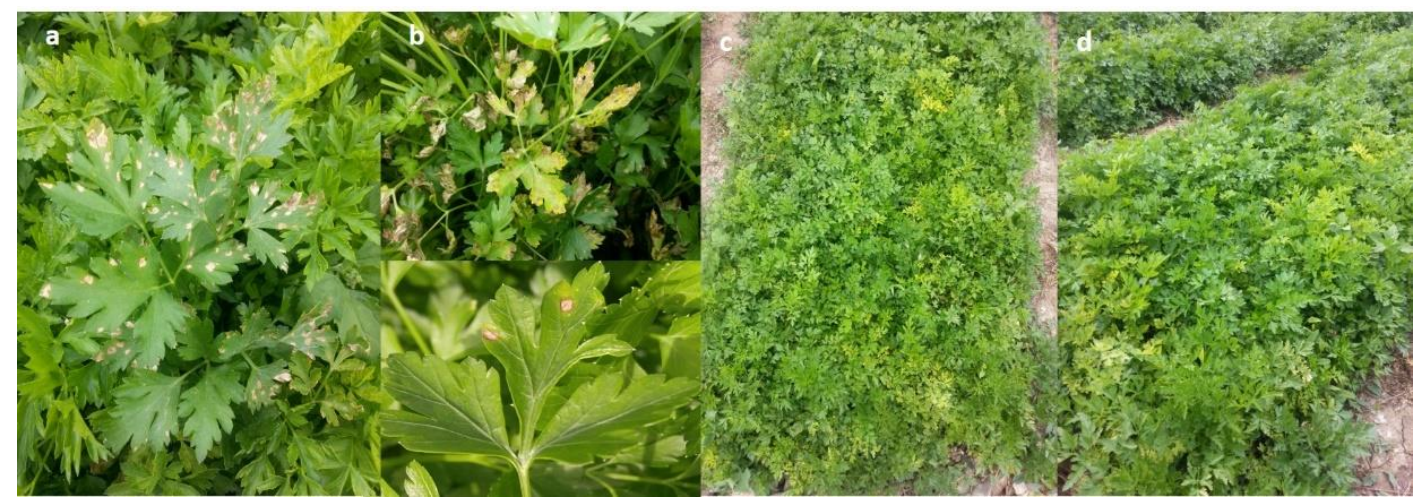

Figure 1. Some fungal diseases in parsley production areas. a-b: Septoria petroselini,c-d: Fusarium oxysporum and Rhizoctonia solani symptoms on the parsley plant.

Disease pathogens that caused significant product and quality loss in the areas of arugula (Eruca sativa) were Albugo candida, Alternaria japonica, Fusarium oxysporum. Albugo candida that causes white rust disease in arugula; in plants where the disease is seen, excessive leaf loss occurs and they cause a decrease in the market value of the product due to the disease symptoms on the leaf (Figure 2). Spinach, which eats other leaves, is the most economically affected plant species in this disease, and dill, arugula and cabbage are the most affected plants. Fungal disease spends adverse conditions such as winter as resistant spores in the soil. Resistant spores of the disease retain their vitality in the soil for many years and, when they find suitable hosts, they carry out their infections. In the control against the disease, disease-free plants should be planted in the field or greenhouse, crop rotation should be done and plants infected with the disease should be destroyed. The possibility of seeds being contaminated should be taken into consideration, and hot water application or seed spraying can be done. White rust disease was detected in rocket (arugula) plants produced in California in 1999 (Scheck and Koike, 1999). In Argentina, which produces largely arugula, a disease that appeared in the fields and greenhouses in the fall of 2002 and spread to the entire production area was observed. It was determined that the disease that causes yellowing on the leaves and the formation of a white problem under the leaf is white rust (Zapata et al., 2005). In a study conducted in order to determine pathogenic fungal disease and their incidence rates in fruits and vegetables offered for consumption in the Central Anatolia Region, Albugo candida in arugula, Alternaria spp. in parsley, Bremia lactucae in lettuce were detected (Ünlü and Boyraz 2010).

In Italy, in 2010-2011, during the autumn and winter, the disease that caused excessive necrosis in the arugula leaves was detected. The cause of this disease, which affects $30-40 \%$ of the plants, was identified as Alternaria japonica (Garibaldi et al., 2011). In Northern Italy between 2002 and 2004, the pathogens that caused wilted arugula. Fusarium oxysporum f.sp. raphani ve $F$. oxysporum f.sp. 
conglutinans were found for the first time (Catti et al., 2007). In arugula vegetable; trials have been established to evaluate the effectiveness of some Pseudomonas ve Achromobacter, Serratia isolates against Fusarium wilt (Figure 2). In addition, two commercial biopreparats (Trichoderma harzianum strain KRL-AG2; Pseudomonas chlororaphis strain MA342) have been tested. It has been observed that applications significantly reduce the occurrence of disease at values ranging from $87 \%$ to $92 \%$ (Srinivasan et al., 2009).

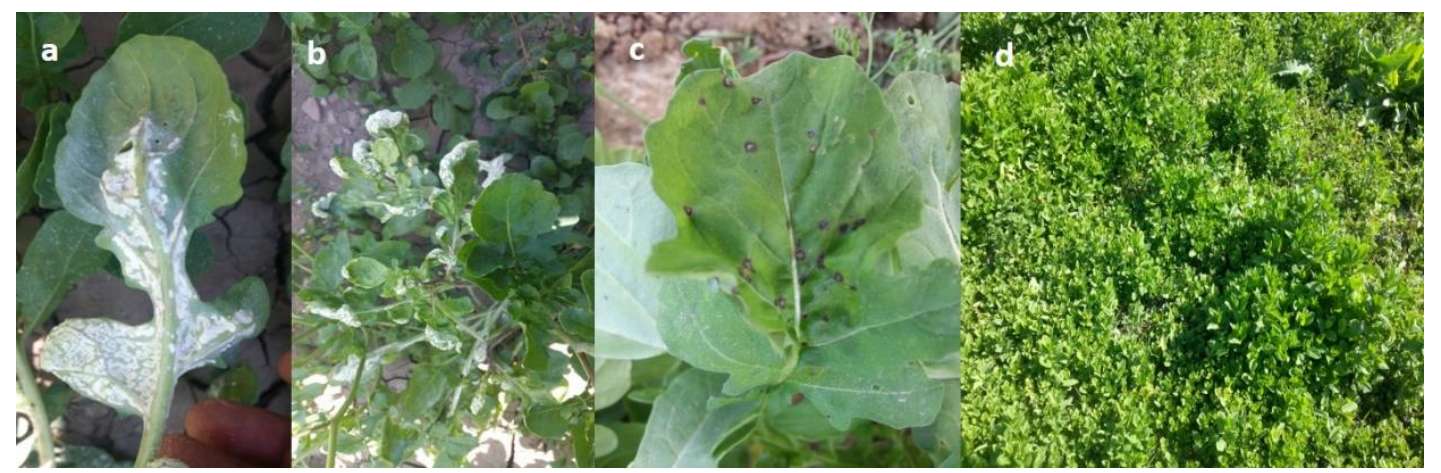

Figure 2. Some fungal diseases seen in arugula and mint production areas. a-b: Albugo candida, c: Alternaria japonica, d: Fusarium wilt on mint

Mint, a vegetable that eats a perennial aromatic leaf, has a great importance in the class of medicinal plants in terms of its etheric oils and especially menthol and tannins. Soil-borne pathogens are among the most common fungal diseases in mint cultivation. The most important pathogens seen in mint plant are Verticillium wilt, Fusarium wilt, Rhizoctonia solani, mint rust (Figure 2). The soil-borne pathogens detected in the study cause the mint plant to fade and dry, causing a decrease in yield and quality. Plants that show symptoms of disease in the disease control should be removed and crop raotation should be given importance (Kalra et al.2005; Demir, 2007).

The most common fungal disease pathogens in spinach grown areas is white rust disease caused by Albugo occidentalis, with low rates of Colletotrichum dematium, Cercospora beticola, Peronospora farinosa f.sp. spinaciae and Fusarium oxysporum have been identified (Correl et al., 1994; Larsson et al., 1992; Dainiello et al., 1990). (Figure 3). In the control against white rust disease in spinach, the metalaxyl agent was applied to sensitive and partially resistant spinach varieties, and it was observed that the disease delayed the occurrence of symptoms but did not decrease the disease level (Dainello et al., 1990). Cyprodinil + fludioxonil against Cercospora leaf spot in plant protection programs of the University of Florida, Bacillus subtilis strain QST 713 against mildew applications were made (Raid and Roberts, 2009). Cercospora beticola seen in spinach; many vegetable species, especially spinach, sugar beet, field crops and a very large weed host host this fungus. The disease initially appears on the first symptoms of the leaves, and then the younger leaves show signs of the disease. Black conidispores can be easily seen on the disease spots on the leaves. At least 3 years of crop rotation should be made in places where the disease is observed every year and all cultural measures should be taken. Great attention should be paid to plant feeding and watering. Especially, irrigation done over the plant should not be long-term and care should be taken not to keep the plants wet. In the control against the fungal pathogen, as soon as the first symptoms are seen, spraying with licensed drugs should be done, and the subsequent spraying should be arranged according to the environment and cultivated variety, which is effective in the development of the disease (Anonymous, 2020). When we look at the studies on the control against fungal diseases detected in leafy vegatables around the world, it can be seen that it is made on the effectiveness of biological preparations that do not have any residue problem. Some of those; biological preparations such as Streptomyceslydicus strain WYEC 108, Streptomyces griseoviridis strain KG1, Trichoderma harzianum strain KRL-AG2, Trichoderma harzianum strain T22, Reynoutria sachalinensis, Bacillus subtilis are available in the production of organic spinach against diseases caused by soil-borne pathogens (Seaman, 2016). 


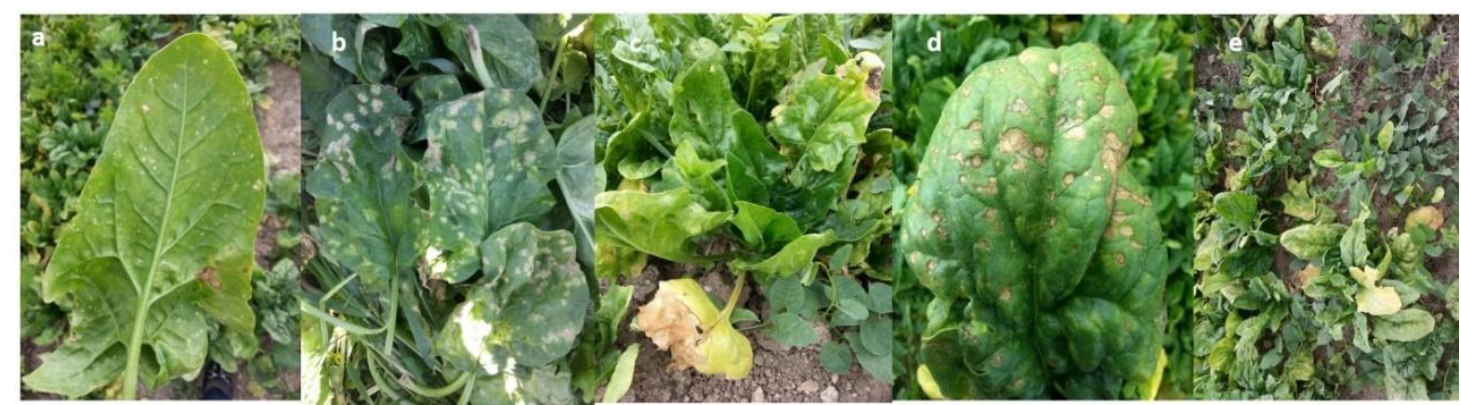

Figure 3. Some fungal diseases in spinach production areas. a-b: Albugo occidentalis, c: Peronospora farinosa f.sp. spinaciae, d: Cercospora beticola, e: Fusarium oxysporum

In the cultivation of lettuce, which is rich in nutritional value; The most common fungal disease in the region was white mold caused by Sclerotinia sclerotiorum. (Figure 3). The disease was mostly detected in Güzelyurt county. Disease is a difficult disease pathogen to control due to the resistant structures formed in the soil. Today, in the control against the disease pathogen, there is a loss of 5 to $40 \%$ due to the potential rapid degradation of the existing fungicides in the soil. It has been reported that the product losses caused by white rot disease caused by the cause of Sclerotinia sclerotiorum in lettuce production reach up to 95\% in the world (Clarkson et al., 2004; Smolinska and Kowalska, 2018; Çolak, 2019; Mullen, 2001; Chitrampalam et al., 2010). It was reported that in Sclerotinia sclerotiorum intensive infected fields, the plant completely died, and in less-infected fields, it lost market value due to losses in the size and weight of the crops. In many studies on the control against Sclerotinia sclerotiorum disease pathogen, many researchers have stated that the use of fungicide does not harm the environment, it does not have reliability in freshly consumed products, and that fungicides increase the resistance of diseases. Many studies have reported that mycoparatic fungi are effective in Sclerotinia disease. The most used of these are Coniothyrium minitans, Trichoderma harzianum, Bacillus subtilis and Streptomyces lydicus species (Tomprefa et al., 2011; Villalta et al., 2012; Çolak, 2019).The effectiveness of Coniothyrium minitans (C) and Trichoderma harzianum (TH), which are alternative biological control agents in the control of Sclerotinia sclerotiorum, in single and combined applications, was investigated in two lettuce fields. While the highest \% effect on Sclerotinia sclerotiorum in both lettuce trial areas was $80-86.05 \%$ in $\mathrm{C}(4 \mathrm{~kg} / \mathrm{ha})+\mathrm{TH}$ co-application, the lowest effect was obtained from TH application only with 54-60.47\% (Colak, 2019). Fungal diseases in studies conducted in Turkey; reported that Sclerotinia sclerotiorum in lettuce was heavily damaged in İzmir, Manisa and Aydın provinces in the Aegean Region (Onaran andYanar, 2009).

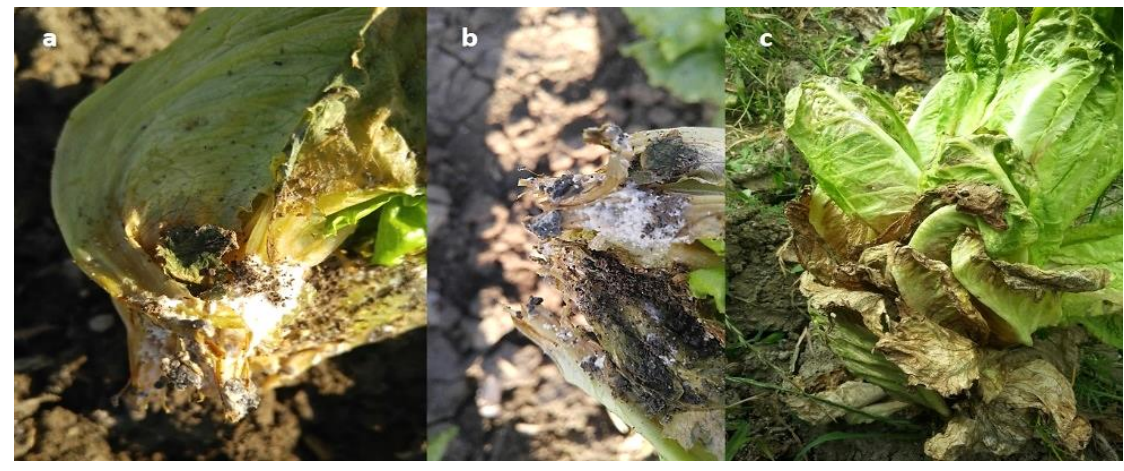

Figure 3. Important fungal diseases in lettuce production areas. a-b: Sclerotinia sclerotiorum, b: Bremia lactucae 
Table 1. Number and area of sampled fields in some leafy vegetables.

\begin{tabular}{|c|c|c|c|c|c|c|c|c|c|c|}
\hline \multirow[b]{2}{*}{ County } & \multicolumn{2}{|c|}{ Rarsley } & \multicolumn{2}{|c|}{ Arugula } & \multicolumn{2}{|c|}{ Mint } & \multicolumn{2}{|c|}{ Spinach } & \multicolumn{2}{|c|}{ Lettuce } \\
\hline & $\begin{array}{l}\text { Field } \\
\text { number }\end{array}$ & $\begin{array}{l}\text { Field } \\
\text { area } \\
\text { (da) }\end{array}$ & $\begin{array}{l}\text { Field } \\
\text { number }\end{array}$ & $\begin{array}{l}\text { Field } \\
\text { area } \\
\text { (da) }\end{array}$ & $\begin{array}{l}\text { Field } \\
\text { number }\end{array}$ & $\begin{array}{l}\text { Field } \\
\text { area } \\
\text { (da) }\end{array}$ & $\begin{array}{l}\text { Field } \\
\text { number }\end{array}$ & $\begin{array}{l}\text { Field } \\
\text { area } \\
\text { (da) }\end{array}$ & $\begin{array}{l}\text { Field } \\
\text { number }\end{array}$ & $\begin{array}{l}\text { Field } \\
\text { area } \\
\text { (da) }\end{array}$ \\
\hline Gazimağusa & 4 & 11.4 & 1 & 1.3 & 2 & 4 & 5 & 14.1 & 9 & 46.2 \\
\hline Lefkoşa & - & - & - & - & - & - & - & - & 2 & 11.4 \\
\hline Güzelyurt & 6 & 14.8 & 2 & 3.3 & 3 & 3.3 & 9 & 22.1 & 12 & 64.8 \\
\hline İskele & 1 & 2 & - & - & - & - & 2 & 4.7 & 2 & 7.4 \\
\hline Girne & 3 & 3.3 & 1 & 1.3 & 2 & 5.4 & 3 & 8.6 & 5 & 22.7 \\
\hline Total & 14 & 134.1 & 4 & 5.9 & 7 & 12.7 & 19 & 49.5 & 30 & 152.5 \\
\hline $\begin{array}{l}\text { General Total } \\
\text { (number/da) }\end{array}$ & & & & & $4 / 35$ & & & & & \\
\hline
\end{tabular}

Table 2. Fungal disease pathogens and prevalence detected in some leafy vegetables.

\begin{tabular}{|c|c|c|c|c|c|c|}
\hline \multirow[b]{2}{*}{ County } & \multirow[b]{2}{*}{ Fungal pathogen } & \multicolumn{5}{|c|}{ Prevalence rate $(\%)$} \\
\hline & & Parsley & Arugula & Mint & Spinach & Lettuce \\
\hline \multirow[t]{13}{*}{ Güzelyurt } & Albugo candida & - & 20.41 & - & - & - \\
\hline & Albugo occidentalis & - & - & - & 18.16 & - \\
\hline & Alternaria petroselini & 2.23 & - & - & - & - \\
\hline & Alternaria japonica & - & 2.65 & - & - & - \\
\hline & Bremia lactucae & - & - & - & - & 18.72 \\
\hline & Cercospora beticola & - & - & - & 3.84 & - \\
\hline & Colletotrichum dematium & - & - & - & 7.64 & - \\
\hline & Septoria petroselini & 29.26 & - & - & - & - \\
\hline & Sclerotinia sclerotiorum & - & - & - & - & 36.28 \\
\hline & Peronospora farinosa f.sp. spinaciae & - & - & & 1.16 & - \\
\hline & Verticillium dahliae & - & - & 1.89 & - & - \\
\hline & Rhizoctonia solani & 1.12 & 1.09 & 8.20 & - & - \\
\hline & Fusarium oxysporum & 12.35 & & 6.53 & - & 1.67 \\
\hline \multirow[t]{13}{*}{ Gazimağusa } & Albugo candida & - & 16.72 & - & - & - \\
\hline & Albugo occidentalis & - & - & - & 26.65 & - \\
\hline & Alternaria petroselini & 6.91 & - & - & - & - \\
\hline & Alternaria japonica & - & 1.44 & - & - & - \\
\hline & Bremia lactucae & - & - & - & - & 13.67 \\
\hline & Cercospora beticola & - & - & - & 1.83 & - \\
\hline & Colletotrichum dematium & - & - & - & 2.24 & - \\
\hline & Septoria petroselini & 22.45 & - & - & - & - \\
\hline & Sclerotinia sclerotiorum & - & - & - & - & 28.50 \\
\hline & Peronospora farinosa f.sp. spinaciae & - & - & & 1.22 & - \\
\hline & Verticillium dahliae & - & - & - & - & - \\
\hline & Rhizoctonia solani & 0.50 & - & 12.14 & - & - \\
\hline & Fusarium oxysporum & 14.64 & 1.16 & 8.83 & - & - \\
\hline \multirow[t]{13}{*}{ Girne } & Albugo candida & - & 8.82 & - & - & - \\
\hline & Albugo occidentalis & - & - & - & 15.98 & - \\
\hline & Alternaria petroselini & 3.52 & - & - & - & - \\
\hline & Alternaria japonica & - & 1.36 & - & - & - \\
\hline & Bremia lactucae & - & - & - & - & 8.74 \\
\hline & Cercospora beticola & - & - & - & 1.91 & - \\
\hline & Colletotrichum dematium & - & - & - & 1.54 & - \\
\hline & Septoria petroselini & 2.83 & - & - & - & - \\
\hline & Sclerotinia sclerotiorum & - & - & - & - & 18.32 \\
\hline & Peronospora farinosa f.sp. spinaciae & - & - & & - & - \\
\hline & Verticillium dahliae & - & - & - & - & - \\
\hline & Rhizoctonia solani & 2.15 & - & - & - & - \\
\hline & Fusarium oxysporum & - & - & 3.27 & 2.62 & 1.23 \\
\hline
\end{tabular}




\begin{tabular}{|c|c|c|c|c|c|c|}
\hline \multirow[t]{12}{*}{ İskele } & Albugo candida & - & - & - & - & - \\
\hline & Albugo occidentalis & - & - & - & 2.14 & - \\
\hline & Alternaria petroselini & 1.62 & - & - & - & - \\
\hline & Alternaria japonica & - & - & - & - & - \\
\hline & Bremia lactucae & - & - & - & - & 2.37 \\
\hline & Cercospora beticola & - & - & - & 1.12 & - \\
\hline & Colletotrichum dematium & - & - & - & - & - \\
\hline & Septoria petroselini & 1.23 & - & - & - & - \\
\hline & Sclerotinia sclerotiorum & - & - & - & - & 8.18 \\
\hline & Peronospora farinosa f.sp. spinaciae & - & - & & - & - \\
\hline & Rhizoctonia solani & - & - & - & - & - \\
\hline & Fusarium oxysporum & - & - & - & 8.41 & - \\
\hline \multirow[t]{12}{*}{ Lefkoşa } & Albugo candida & - & - & - & - & - \\
\hline & Albugo occidentalis & - & - & - & - & - \\
\hline & Alternaria petroselini & - & - & - & - & - \\
\hline & Alternaria japonica & - & - & - & - & - \\
\hline & Bremia lactucae & - & - & - & - & 8.22 \\
\hline & Cercospora beticola & - & - & - & - & - \\
\hline & Colletotrichum dematium & - & - & - & - & - \\
\hline & Septoria petroselini & - & - & - & - & - \\
\hline & Sclerotinia sclerotiorum & - & - & - & - & 15.42 \\
\hline & Peronospora farinosa f.sp. spinaciae & - & - & & - & - \\
\hline & Rhizoctonia solani & - & - & - & - & - \\
\hline & Fusarium oxysporum & - & - & - & - & 1.48 \\
\hline
\end{tabular}

\section{Conlusion}

In the world, it has been inevitable to increase the production of vegetables, which provide different usage possibilities to supply raw materials to the rapidly growing human population for food and agricultural industry. Fungal diseases seen in the cultivation of leafy vegatables rich in nutritional value, decrease the market value of the product and cause significant efficiency losses in areas heavily contaminated with the fungal disease. In the study, the type of fungal disease from farm to field in the fields of parsley, arugula, mint, spinach and lettuce, which were eaten with leaves, differed. Since the studies on these products are very few, there is no solution for most of the plant protection problems. The preparations used by the producers for the unconscious application, can lead to residue in these products with a short vegetation period. Therefore, it is observed that the cultivation areas of these leafy vegetables are low in the region and the probability of residue in terms of chemical control in these products leads the producer to mechanical and cultural measures. In the leafy vegetables; It is important to take necessary cultural measures before fungal disease is transmitted to the plant. Because the control methods to be performed after the fungal disease pathogen is contaminated with the plant, is not both less, difficult and very effective. In this context, it is important to investigate biological control possibilities in these products in recent years due to the residual risks of the product resulting from excessive and unconscious use of chemicals in the control of fungal diseases.

\section{Acknowledgements}

This work is part of the project named "Determination of Disease, Pest and Weeds for the Principles of Quarantine and Certification in the Turkish Republic of Northern Cyprus". Author would like to thank the General Directorate of Agricultural Research and Policies/Turkey and the Northern Cyprus Department of Agriculture for their contributions.

\section{REFERENCES}

Agrios, G. N., (2005). Plant Pathology, Fifth Edition. Elsevier Academic Press, USA.

Alonso, W.R., Rajaonarivony, J.I.M., Gershenzon,J., \& Croteau, R. (1992). Purification of $4 S$ limonene synthase, a monoterpene cyclase from the glandular trichomes of peppermint $($ Mentha $\times$ piperita $)$ and spearmint (M. spicata). J Biol Chem 267:7582-7587. 
Anonymous (2017). Kuzey Kıbrıs Türk Cumhuriyeti Tarım Ve Doğal Kaynaklar Bakanlığı Tarım Master Planı Raporu.

Anonymous (2020). Bitki Sağlı̆̆, web site:http://www.bitkisagligi.net

Booth, C. (1971). Fusarium a laboratory guide to the identification of the major species. C.M.I. Kew surrey, England pp.58.

Bora, T. \& Karaca, I. (1970). Kültür Bitkilerinde Hastalığın ve Zararın Ölçülmesi, Ege Üniversitesi Ziraat Fak. Yardımc1 Ders Kitab1, No:167, Ege Üniversitesi Matbaas1, Bornova, $43 \mathrm{~S}$.

Budge, S. P. \& Whipps, J. M. (2001). Potential for integrated control of Sclerotinia sclerotiorum in glasshouse lettuce using Coniothyrium minitans and reduced fungicide application. Phytopathology 91:221-227.

Catti, A., Pasqual1, M., Ghirınghell1, D., Garibald1, A. \& Gullino, M.L. (2007). Analysis of vegetative compatibility groups of Fusarium oxysporum from Eruca vesicaria and Diplotaxis tenuifolia. Journal of Phytopathology 155 (1), 61-64

Chitrampalam, P., Wu, B. M., Ko1ke, S.T. \& Subbarao, K.V. (2011). Interactions between Coniothyrium minitans and Sclerotinia minor affect biocontrol efficacy of $C$. minitans. Phytopathology 101: 358-366.

Clarkson, J.P., Phelps, K., Whipps, J.M., Young, C.S., Smith, J.A., \& Watling, M. (2004). Forecasting Sclerotinia disease on lettuce: toward developing a prediction model for carpogenic germination of sclerotia. Phytopathology 94:268-279

Correll, J.C., Morelock, T.E., Black, M.C., Ko1ke, S.T., Brandenberg, L.P. \& Dainello, F.J., (1994). Economically important diseases of spinach, Plant Disease, 78(7), 653-660.

Çolak, A., \& Biçici, M. (2013). Integrated Disease Management of Fusarium Crown and Root Rot of Greenhouse-Grown Tomato in Eastern Mediterranean Region of Turkey. Journal of Agricultural Sciences 19 (2013) 89-100.

Çolak, A.A., Dinçer, D. \& Ata, A. (2018). Determination of The Interaction Between Fusarium Crown - Root Rot Disease and Root-Knot Nematode on Tomato Genotypes. Fresenius Environmental Bulletin, Volume 27 - No. 10/2018 pages 6785-6791.

Çolak, A.A. (2019). Effect of Coniothyrium minitans and Trichoderma harzianum in the biological control of white mold disease (Sclerotinia sclerotiorum) in lettuce (Lactuca sativa L.). Applied Ecology and Environmental Research 17(6):15687-15701.

Dainiello, F.J., Black, M.C. \& Kunkel, T.E. (1990). Control of white rust of spinach with partial resistance and multiple soil applicationa of metalaxyl granules. Plant Disease, 74,913-916

Demir, H. (2007). Yaprağı Yenen Sebzeler. Hasat yayıncılık. ISBN: 978-975-8377-60-2. p:1-192.

Ellialtıŏlu, Ş., Sevengör, Ş. \& Sezik, E. (2007). Şanlıurfa'da Nane Tarımının Geliştirilmesi Üzerinde Çalışmalar. Şanlıurfa Gap Gidem Bilgilendirme Toplantısı, 30 Mart 2007, web site: http://iller.gidem.org/Sanliurfa/ TibbiAromatikBitkiler.aspx) 
Feng, C., Correll, J. C., Kammeijer, K. E. \& Koike, S. T. (2014). Identification of new races and deviating strains of the spinach downy mildew pathogen Peronospora farinosa $\mathrm{f}$. sp. spinaciae. Plant Dis. 98:145-152.

Fiddaman, P.J., O'neill T.M. \& Rossall, S. (2000). Screening of bacteria for the suppression of Botrytis cinerea and Rhizoctonia solani on lettuce (Lactuca sativa) using leaf disc bioassays. Annals of Applied Biology137 (3): 223-235

Fiume, F. \& Fiume, G. (2005). Biological control of Botrytis gray mould and Sclerotinia drop in lettuce. Comm. Appl. Biol. Sci, Ghent University, 70/3:157-168

Garibaldi, A., Gilardi, G., Bertoldo, C. \& Gullıno, M.L. (2011). First Report of Leaf Spot of Wild (Diplotaxis tenuifolia) and Cultivated (Eruca vesicaria) Rocket Caused by Alternaria japonica in Italy. Plant Disease, 95 (10): 315.

Glawe, D.A., Pelter, G.Q. \& Du Toit, L.J. (2005). First report of powdery mildew of carrot and parsley caused by Erysiphe heraclei in Washington State, Online. Plant Health Progress doi:10.1094/PHP-2005-0114-01-HN.

Gupta, S. \& Prakash, J. (2009). Studies on Indian green leafy vegetables for their antioxidant activity, Plant Foods Hum. Nutr., 64, 39-45

Hershman, D.E. (1986). Etiology of parsley damping-off and influence of temperature on disease development. Plant Disease, 70, 927-930

Irish, B.M., Correll, J.C., Koike, S.T. \& Morelock, T.E. (2007). Three new racesof the spinach downy mildew pathogen identified by a modified set of spinach differentials. Plant Disease, 91, 1392-1396.

Kalra, A., H. B. Singh., R. Pandey. A., Samad. N. K. Patra \& Sushil Kumar (2005). Diseases in Mint: Causal Organisms Distribution and Control Measures. Journal of Herbs. Spices \& Medicinal Plants. 11:1-2. 71-91. DOI: 10.1300/J044v11n01_03

Karman, M. (1971). Bitki Koruma Araştırmalarında Genel Bilgiler, Denemelerin Kuruluşu ve Değerlendirilme Esasları, Bölge Zir. M.A. Enst. İzmir. Tar. Bak. Zir. Müc. ve Kor. Genel Müd. Yayınlar1,1971.

Koike, S.T., Gladders, P. \& Paulus, A.O. (2007). Vegetable Diseases: A Color Handbook. Gulf Professional Publishing, $448 \mathrm{p}$

Kurt, S. (2003). First report of Septoria blight of parsley caused by Septoria petroselini in the Mediterranean Region of Turkey, Plant Disease, 87(1), 99

Larsson, M. \& Gerhardson, B. (1992). Disease progression and yield losses from root diseases caused by soilborne pathogens of spinach. Phytopathology 82: 403-406.

Mordue, J. E. (1974). CMI Descriptions of Pathogenic Fungi and Bacteria. No. 410. CAB International, Wallingford, U.K.

Mullen, J. (2001). The Plant Health Instructor. Southern blight, Southern stem blight, White mold. The Plant Health Instructor. DOI: 10.1094/PHI-I-2001-0104-01 
Nawrocki, J. (2004). Occurence of fungal diseases on parsley seedlings (Petroselinum sativum Hoffm.). Acta fytotechnica et zootechnica, 7, 220-223

Onaran, A. \& Yanar, Y. (2009). Türkiye'de Sclerotinia sclerotiorum (Lib.) De Bary Üzerinde Yapılan Çalışmalar. Türk Bilimsel Derlemeler Dergisi 2(2): 7

Özgüven, M. \& Kırıcı S. (1999). Farklı Ekolojilerde Nane Türlerinin Verim ile Uçucu Yağ Oran ve Bileşenlerinin Araştırılması. T. J. of. Agr. And Forestry, 23, 5, s. 465-472.

Raid, R. \& Roberts, P. (2009). Florida Plant Disease Management Guide: Parsley, Institue of Food and Agricultural Sciences, University of Florida (IFAS) Extension, 2p.

Scheck, H.J. \&Ko1ke, S.T. (1999). First occurrence of white rust of arugula, caused by Albugo candida. Plant Disease 83(9), 877

Seaman, A. 2016. Organic Production and IPM Guide for Spinach. NYS IPM Publication No. 139; $\mathrm{P}: 20-33$.

Sherf, A. F., \& MacNab, A. A. (1986). Vegatable Diseases and Their Control. Secon edition, Printed in The United States of America ISBN: 0-471-05860-2, p:30-31.

Singleton, L.L., Mihail J.D., \& Rush, C.M. (1992). Methods for Research on Soilborne Phytopathogenic Fungi. APS press, pp.266. St. Paul, Minnesota. U.S.A.

Singleton, L.L., Mihail J.D., \& Rush, C.M. (1992). Methods for Research on Soilborne Phytopathogenic Fungi. APS press, pp.266. St. Paul, Minnesota.U.S.A.

Smolinska, U., \& Kowalska, B. (2018). Biological control of the soil-borne fungal pathogen Sclerotinia sclerotiorum, a review. Journal of Plant Pathology, 100:1-12.

Sneh, B., Burpee, L., \& Ogoshi, A. (1991). Identification of Rhizoctonia species. The American Phytopathological Society, APS press St. Paul, M.N., U.S.

Soylu, S., Soylu E.M. \& Kurt Ş. (2010). Downy mildew outbreak on parsley caused by Plasmopara petroselini in Turkey, 59 (4), 799

Srinivasan, K., Gilardi, G., Garibald, A. \& Gullino M.L. (2009). Efficacy of bacterial antagonists and different commercial products against Fusarium wilt on rocket, Phytoparasitica, 37(2), 179188

Tok, F. M.(2008). Chemical control of Septoria blight of parsley caused by Septoria petroselini. Turk J Agric For 32: 487-494

Tok, F.M. \& Kurt, Ş. (2019). The effect of hot water treatment on seed transmission of Septoria petroselini, the causal agent of septoria blight on parsley. MKU. Tar. Bil. Derg. 24(3) : 210-216

Tomprefa, N., Hill, R.,Whipps, J. \& McQuilken, M. (2011). Some environmental factors affect growth and antibiotic production by mycoparasite Coniothyrium minitans. Biocontrol Sci Tech 21:721-731.

Ünlü, M.H. \& Boyraz, N. (2010). Konya İlinde tüketime sunulan meyve ve sebzelerde patojen fungal flora ve bulunuş oranlarının belirlenmesi, Selçuk Tarım ve Gıda Bilimleri Dergisi, 24(1), 70-79 
Villalta, O. N.,Wite, D., Hunt, J., Stewart, A. \& Porter, I.J. (2012). Biological control of Sclerotinia minor on lettuce using Trichoderma and Coniothyrium species. Acta Horticulturae, Volume 944, 26 April 2012,51-58 pp.

Washington, W. S., Irvine, G., Aldaoud, R., Dealwis, S., Edwards, J. \& Pascoe, I.G. (2006). First Record of Anthracnose of Spinach Caused By Colletotrichum dematium in Australia. Australasian Plant Pathology, 35, 89-91.

Zapata, R., Romero, A.M. \& Maseda, P.H. (2005). First report of white rust of arugula caused by Albugo candida in Argentina, Plant Disease, 89 (2), 207. 